
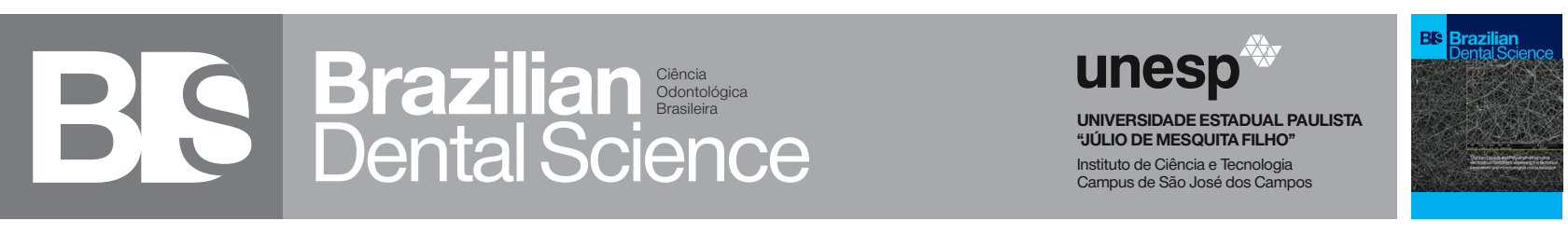

\title{
Biaxial flexural strength of different types of monolithic zirconia
}

Resistência Flexural Biaxial de diferentes tipos de zircônia monolítica

Shereen NOSSAIR ${ }^{1}$, Tarek SALAH ${ }^{2}$, Kamal EBEID ${ }^{2}$

1 - Department of Fixed Prosthodontics - Faculty of Dentistry - Future University in Egypt - Egypt.

2 - Department of Fixed Prosthodontics - Faculty of Dentistry - Ain Shams University - Egypt.

\section{ABSTRACT}

Objective: This study was designed to evaluate the biaxial flexural strength (BFS) of different types of unshaded and shaded monolithic zirconia. Material and Methods: 120 monolithic zirconia ceramic discs were fabricated. They were divided into twelve groups $(n=10)$, Group 1; Bruxzir unshaded, Group 2; Bruxzir shaded A2, Group 3; Bruxzir anterior white, Group 4; Bruxzir anterior shade A2, Group 5; Prettau unshaded, Group 6; Prettau shaded with A2 coloring liquid, Group 7; Prettau anterior white, Group 8; Prettau anterior shaded with A2 coloring liquid, Group 9; Katana HT white, Group 10; Katana HT shade A2, Group 11; Katana ST white, Group 12; Katana ST shade A2. All discs were milled using a dental milling machine, and had final dimensions after sintering of $15 \mathrm{~mm}$ diameter and $1 \mathrm{~mm}$ thickness. BFS was tested using piston on three ball technique. Results: One-way ANOVA revealed significant differences among the 12 groups. Tukey post-hoc tests revealed no significant differences between the groups 3,4 , ,7 ,8 11, and 12. However, they all had BFS values that are significantly lower than all other groups. Group 2 showed statistically significant higher BFS values when compared to group $3,4,7,8,11$, and 12 while it showed statistically significant lower values when compared to groups $1,5,6,9$, and 10. Conclusion: Increase in the yttria content in zirconia led to a decrease in its BFS. Shading of zirconia did not have a significant effect on the final strength of zirconia.

\section{KEYWORDS}

Dental ceramics; Dental esthetics; Flexural strength; Shaded zirconia.

\section{RESUMO}

Objetivo: Este estudo foi desenhado para avaliar a resistência à flexão biaxial (RFB) de diferentes tipos de zircônia monolítica maquiada e não-maquiadas. Material e Métodos: 120 discos cerâmicos de zircônia monolítica foram fabricados. Eles foram divididos em doze grupos $(\mathrm{n}=10)$, Grupo 1; Bruxzir Não-maquiado, Grupo 2; Bruxzir maquiado A2, Grupo 3; Branco anterior de Bruxzir, Grupo 4; Maquiagem anterior de Bruxzir A2, Grupo 5; Prettau não maquiado, Grupo 6; Prettau maquiado com corante A2, Grupo 7; Prettau anterior branco, Grupo 8; Prettau anterior maquiado com corante A2, Grupo 9; Katana HT branco, Grupo 10; Katana HT maquiagem A2, Grupo 11; Katana ST White, Grupo 12; Katana ST maquiagem A2. Todos os discos foram fresados em uma fresadora dentária e tiveram suas dimensões finais após sinterização de $15 \mathrm{~mm}$ de diâmetro e $1 \mathrm{~mm}$ de espessura. A RFB foi testado usando pistão na técnica de três bolas. Resultados: One-way ANOVA revelou diferenças significativas entre os 12 grupos. Os testes post-hoc de Tukey não revelaram diferenças significativas entre os grupos 3, 4, 7, 811 e 12. No entanto, todos eles exibiram valores de RFB significativamente menores do que todos os outros grupos. O Grupo 2 apresentou valores estatisticamente significantes de ICS mais elevados quando comparado aos grupos 3,4, 7, 8, 11 e 12, enquanto apresentou valores estatisticamente significantes menores quando comparados aos grupos 1, 5, 6, 9 e 10. Conclusão: o aumento do conteúdo de ítria na zircônia levou a uma diminuição em sua RFB. A maquiagem da zircônia não teve um efeito significativo sobre a resistência final da zircônia.

\section{PALAVRAS-CHAVE}

Cerâmicas dentais; Estética Dental; Resistência Flexural; Zircônia. 


\section{INTRODUCTION}

T $T$ ith the increasing demands for esthetics and natural looking restorations, allceramic restorations gained their popularity mainly due to their excellent esthetics and biocompatibility [1]. However, due to their limited use as long span restorations zirconia restorations were introduced and proved their success due to their unique fracture strength and toughness $[2,3]$.

Zirconia is a polycrystalline ceramic without any glass component. It is polymorphic in nature and exists in three forms: cubic, tetragonal, and monoclinic. At room temperature zirconia is present in its monoclinic form and is stable up to $1,170^{\circ} \mathrm{C}$. Above this temperature a transformation occurs to the tetragonal phase that is stable up to $2,370^{\circ} \mathrm{C}$. Beyond this temperature, zirconia assumes its cubic form [4]. Addition of stabilizing oxides such as calcium oxide, magnesium oxide, cerium oxide and yttrium oxide stabilizes zirconia in its tetragonal phase at room temperature. Stresses at the crack tip will cause the tetragonal crystals to transform to monoclinic ones accompanied by a $3 \%$ to $5 \%$ localized expansion. This phenomenon cause retardation of the crack and is known as transformation toughening [2].

Initially, dental zirconia ceramic had a whitish color and was considered opaque and not being esthetic; thus the zirconia core was veneered with veneering porcelain in order to enhance its esthetic potential. However, the most common cause of failure that faced clinicians was chipping of this veneering porcelain while the zirconia core remained unaffected. This led to the introduction of monolithic translucent zirconia ceramic which allows their use in a full contoured state [5-7].

In order to produce monolithic zirconia with acceptable translucency, processing of the next generation of 3Y-TZPs was improved by drastically reducing the concentration of alumina additive and eliminating porosity by sintering at a higher temperature. This led to slight improvement in translucency [8]. Although suitable for monolithic posterior restorations, this generation of zirconia was not esthetic enough to be used in monolithic anterior restorations. The next generation in monolithic zirconia included some transparent phase in the final product to reduce opacity. This was achieved by using a higher yttria content to produce partially stabilized zirconias, $4 \mathrm{~mol} \%$ (4YPSZ) or $5 \mathrm{~mol} \%$ (5Y-PSZ), with increased amounts of nonbirefringent cubic phase. This markedly improved translucency, but strength and toughness were diminished because cubic zirconia does not undergo stress-induced transformation. The most translucent 5Y-PSZ materials were indicated for broad usage as anterior crowns and FDPs [9].

Flexural strength is considered one of the most important parameters assessed to understand the clinical potential and limitation of dental ceramics [10]. It is considered as a meaningful and reliable method to assess the strength of brittle materials $[11,12]$. The literature demonstrated several factors that can affect the biaxial flexural strength of zirconia such as the surface treatment performed, sintering, aging, and finishing procedures [13-18].

Zirconia restorations are either dipped in coloring liquid before their sintering process or brush stained after sintering and subjected later to a firing cycle to achieve their final color. Recently partially sintered pre-shaded monolithic zirconia blanks were introduced. Therefore, the aim of this in-vitro study was to evaluate effect of the yttria content of the zirconia and the effect of the shading technique on the flexural strength of this type of ceramic.

\section{MATERIALS AND METHODS}

Hundred and twenty monolithic zirconia ceramic discs were used in this study. The discs were divided into twelve groups $(n=10)$ (Table 1), Group 1; Bruxzir unshaded (Glidewell, California, USA), Group 2; Bruxzir shaded A2 (Glidewell), Group 3; Bruxzir anterior white (Glidewell), Group 4; Bruxzir anterior shade A2 (Glidewell), Group 5; Prettau unshaded (Zirkonzahn, Gais, Germany), Group 6; Prettau shaded with A2 coloring liquid (Zirkonzahn), 
Group 7; Prettau anterior white (Zirkonzahn), Group 8; Prettau anterior shaded with A2 coloring liquid (Zirkonzahn), Group 9; Katana HT white (Kuraray, Tokyo, Japan), Group 10; Katana HT shade A2 (Kuraray), Group 11; Katana ST white (Kuraray), Group 12; Katana ST shade A2 (Kuraray). All discs were milled using a Datron D5 (Datron AG, Muhltal-Traisa, Germany) dental milling machine, cleaned ultrasonically in 99\% isopropanol solution for $3 \mathrm{~min}$ and then dried with air. Groups 6 and 8 were fully dipped in Zirkonzahn coloring liquid shade A2 for 30 secs then were dried using a drying lamp for 3mins. Discs were then sintered according to their manufacturer sintering instructions in a zirconia sintering furnace (Nabertherm $\mathrm{GmbH}$, Lilienthal, Germany) All discs had final dimensions after sintering of $15 \mathrm{~mm}$ diameter and $1 \mathrm{~mm}$ thickness.

Table 1 - Materials used in this study

\begin{tabular}{|ccc|}
\hline Group & Shading technique & $\mathbf{Y}_{2} \mathbf{O}_{3}$ \\
\hline Group 1: Bruxzir unshaded & Unshaded & $3 \%$ \\
\hline Group 2: Bruxzir shaded A2 & Pre-shaded & $3 \%$ \\
\hline Group 3: Bruxzir Anterior white & Unshaded & $" 5 \%$ \\
\hline Group 4: Bruxzir Anterior shade A2 & Pre-shaded & $" 5 \%$ \\
\hline Group 5: Prettau unshaded & Unshaded & $3 \%$ \\
\hline Group 6: Prettau shade A2 & Dipped in coloring & liquid A2 \\
\hline Group 7: Prettau Anterior white & Unshaded & $>5 \%$ \\
\hline Group 8: Prettau Anterior shade A2 & Dipped in coloring & $>5 \%$ \\
\hline Group 9: Katana HT white & liquid A2 & Unshaded \\
\hline Group 10: Katana HT shade A2 & Pre-shaded & $3 \%$ \\
\hline Group 11: Katana ST white & Unshaded & $>5 \%$ \\
\hline Group 12: Katana ST shade A2 & Pre-shaded & $>5 \%$ \\
\hline
\end{tabular}

\section{Biaxial flexural strength testing}

Specimens were subjected to biaxial flexural strength test using piston-on-three ball technique in a universal testing machine (Z010, Zwick, Ulm, Germany). A $10 \mathrm{~mm}$ diameter metallic platform was constructed, above which rested three $3.2 \mathrm{~mm}$ diameter stainless steel balls that were equidistant from each other. Each disc was placed centrally on the steal balls and load was applied by a piston of $1.4 \mathrm{~mm}$ diameter and $0.5 \mathrm{~mm} / \mathrm{min}$ crosshead speed using the universal testing machine (Figure 2). The fracture load for each specimen was recorded and the biaxial flexural strength was calculated using the following equation:

$$
\mathrm{S}=[-0.2387 \mathrm{P}(\mathrm{X}-\mathrm{Y})] / \mathrm{d} 2
$$

Where: $\mathrm{S}$ : biaxial flexural strength (MPa); P: fracture load (N); d: specimen disk thickness at fracture origin $(\mathrm{mm}) . \mathrm{X}$ and $\mathrm{Y}$ were determined as follows:

$$
\mathrm{X}:(1+\mathrm{u}) \ln (\mathrm{r} 2 / \mathrm{r} 3) 2+[(1-\mathrm{u}) / 2](\mathrm{r} 2
$$
/r3)2

$$
\mathrm{Y}:(1+\mathrm{u})[1+\ln (\mathrm{r} 1 / \mathrm{r} 3) 2]+(1-\mathrm{u})
$$
(r1/r3)2

$\mathrm{v}$ is Poisson's ratio (0.25), $\mathrm{r} 1$ is the radius of the support circle, $\mathrm{r} 2$ is the radius of the loaded area, and $\mathrm{r} 3$ is the radius of the specimen.

\section{Statistical analysis}

The data collected was checked for normal distribution using Kolomgrov-Smirnov and Shapiro-Wilk tests and analyzed using twoway analysis of variance (ANOVA), followed by Tukey's HSD test (SPSS v20, Chicago, IL, USA) at a significance level of $\mathrm{P} \leq 0.05$.

\section{RESULTS}

Two-way ANOVA revealed statistically significant differences between the different groups (Table 2). Regarding zirconia composition, groups with higher yttrium content showed statistically significant lower BFS values in $\mathrm{MPa}(751 \pm 70)$ when compared to groups

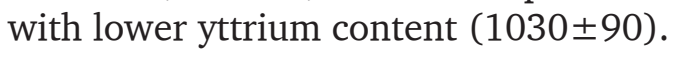

As for the effect of shading on zirconia, groups that were unshaded showed slightly higher BFS values in MPa $(920 \pm 87)$ than groups that were shaded $(860 \pm 73)$ however, this difference was statistically insignificant.

No significant interaction was found between zirconia composition and shading. 
Table 2 - Results of two-way ANOVA

\begin{tabular}{|c|c|c|c|c|c|}
\hline Source & $\begin{array}{l}\text { Type III Sum } \\
\text { of Squares }\end{array}$ & df & $\begin{array}{l}\text { Mean } \\
\text { Square }\end{array}$ & $F$ & Sig. \\
\hline $\begin{array}{c}\text { Corrected } \\
\text { Model }\end{array}$ & $248594.917^{a}$ & 3 & 82864.972 & 118.168 & .000 \\
\hline Intercept & 9517664.083 & 1 & 9517664.083 & 13572.427 & .000 \\
\hline $\begin{array}{l}\text { Zirconia } \\
\text { composi- } \\
\text { tion }\end{array}$ & 233244.083 & 1 & 233244.083 & 332.612 & $<0.001$ \\
\hline Shading & 10980.750 & 1 & 10980.750 & 15.659 & $>0.05$ \\
\hline $\begin{array}{l}\text { Zirconia } \\
\text { compo- } \\
\text { sition* } \\
\text { Shading }\end{array}$ & 4370.083 & 1 & 4370.083 & 6.232 & $>0.05$ \\
\hline
\end{tabular}

One-way ANOVA revealed significant differences among the 12 groups. Tukey posthoc tests revealed no significant differences between the groups $3,4,7,8,11$, and 12 . However, they all had BFS values that are significantly lower than all other groups. Group 2 showed statistically significant higher BFS values when compared to group $3,4,7,8,11$, and 12 while it showed statistically significant lower values when compared to groups $1,5,6$, 9, and 10 (Table 3).

Table 3 - Means $\pm(S D)$ BFS of all groups arranged in descending order

\begin{tabular}{|c|c|}
\hline Group & BFS in MPa \\
\hline Group 10: Katana HT shade A2 & $1009(92)^{\mathrm{ab}}$ \\
\hline Group 1: Bruxzir unshaded & $1058(86)^{\mathrm{a}}$ \\
\hline Group 5: Prettau unshaded & $1088(100)^{\mathrm{a}}$ \\
\hline Group 9: Katana HT white & $1092(112)^{\mathrm{a}}$ \\
\hline Group 8: Prettau Anterior shade A2 & $720(72)^{\mathrm{c}}$ \\
\hline Group 7: Prettau Anterior white & $732(65)^{\mathrm{c}}$ \\
\hline Group 12: Katana ST shade A2 & $735(57)^{\mathrm{c}}$ \\
\hline Group 11: Katana ST white & $753(88)^{\mathrm{c}}$ \\
\hline Group 4: Bruxzir Anterior shade A2 & $765(63)^{\mathrm{c}}$ \\
\hline Group 3: Bruxzir Anterior white & $802(76)^{\mathrm{c}}$ \\
\hline Group 2: Bruxzir shaded A2 & $960(87)^{\mathrm{b}}$ \\
\hline Group 6: Prettau shade A2 & $973(68)^{\mathrm{ab}}$ \\
\hline
\end{tabular}

Means with different superscript letter are statistically significant at a significance value of $p \leq .0 .05$.

\section{DISCUSSION}

Coloring is essential if monolithic zirconia is to be used for a tooth-colored restoration with an appropriate shade and translucency. This can be achieved by adding metal oxides to the zirconia powder at the block manufacture stage or by applying a coloring liquid to the presintered, noncolored zirconia after the milling process.[19,20] Different types of monolithic zirconia blocks were used in the present study according to the coloring procedure: pre-colored (Groups: 2,4,10, and 12), noncolored (Groups: $1,3,5,7,9$, and 11), and colored with immersion technique (Groups: 6 and 8).

Simulating pure bending and preventing edge loss can be achieved best using the piston-on-three ball technique for testing the biaxial flexural strength, as the specimens in this technique are resting on the stainless steel ball which form a smaller diameter than the specimen itself [13].

It is known that a slight variation in the zirconia composition and minute differences in the microstructure can cause a considerable difference in properties. Different dental manufacturers eliminated/reduced the alumina addition or increased the yttria content to improve the translucency of dental restorative3YTZP ceramics $[21,22]$.

In our study groups with higher yttria content $(3,4,7,8,11$, and 12) showed lower BFS, this might be attributed to the fact that these groups have a predominant cubic phase which is a stable phase with very low ability of transformation thus eliminating the main factor behind the high strength of zirconia which is its transformation toughening.

Shaded zirconia had lower BFS values when compared to unshaded zirconia. However, this difference was not statistically significant. This slight decrease might be attributed to the incorporation of foreign metal oxides into the structure of zirconia. This was consistent with several studies in literature [20,23,24]. No difference we also found between zirconia that was pre-shaded and zirconia that's dipped 
in shading liquid. Thus the use of pre-shaded zirconia is more recommended due to its better color stability [25].

It must be stated that the use of highly translucent, non-transformable high yttria content zirconia materials should be carefully assessed. If it is true that these materials may be more translucent than standard 3Y-TZP and do not suffer from in vitro hydrothermal degradation, their strength is dramatically lower. Therefore, manipulation and crown preparation should be done carefully, avoiding thin walls and sharp edges as much as possible and their use must be directed towards shorter span restorations [26].

\section{CONCLUSION:}

Within the limitations of this study we can conclude that:

- Increase in the yttria content in zirconia lead to a decrease in its BFS.

- Shading of zirconia does not have a significant effect on the final strength of zirconia.

\section{REFERENCES}

1. Anusavice KJ. Recent developments in restorative dental ceramics. J Am Dent Assoc. 1993 Feb;124(2):72-4, 76-8, 80-4.

2. Bachhav VC, Aras MA. Zirconia-based fixed partial dentures: a clinical review. Quintessence Int. 2011 Feb;42(2):173-82.

3. Denry I, Kelly JR. State of the art of zirconia for dental applications. Dent Mater. 2008 Mar;24(3):299-307. Epub 2007 Jul 19.

4. Piconi C, Maccauro G. Zirconia as a ceramic biomaterial. Biomaterials. 1999 Jan;20(1):1-25

5. Raigrodski AJ, Hillstead MB, Meng GK, Chung KH. Survival and complications of zirconia-based fixed dental prostheses: a systematic review. J Prosthet Dent. 2012 Mar;107(3):170-7. doi: 10.1016/S00223913(12)60051-1.

6. Vagkopoulou T, Koutayas SO, Koidis P, Strub JR. Zirconia in dentistry: Part 1. Discovering the nature of an upcoming bioceramic. Eur J Esthet Dent. 2009 Summer;4(2):130-51.

7. Zhang H, Kim BN, Morita K, Keijiro Hiraga HY, Sakka Y. Effect of sintering temperature on optical properties and microstructure of translucent zirconia prepared by high-pressure spark plasma sintering. Sci Technol Adv Mater. 2011 Sep 7;12(5):055003. eCollection 20110ct.
8. Tong H, Tanaka CB, Kaizer MR, Zhang Y. Characterization of three commercial Y-TZP ceramics produced for their high-translucency, high-strength and high-surface area. Ceram Int. 2016 Jan 1;42(1 Pt B):1077-1085.

9. Zhang Y, Lawn BR. Novel Zirconia Materials in Dentistry. J Dent Res 2018 Feb;97(2):140-147. doi: 10.1177/0022034517737483. Epub 2017 0ct 16.

10. Carvalho RL, Kimpara ET, Bresciani E, Valera MC, Melo RM. Effect of thermocycling aging on the flexural strength of feldspathic ceramic. Brazilian Dental Science. 2018.21(3):315-9.

11. Bona AD, Anusavice KJ, DeHoff PH. Weibull analysis and flexural strength of hot-pressed core and veneered ceramic structures. Dent Mater. 2003 Nov;19(7):662-9.

12. Guazzato M, Albakry M, Swain MV, Ironside J. Mechanical properties of In-Ceram Alumina and In-Ceram Zirconia. Int J Prosthodont. 2002 Jul-Aug;15(4):339-46.

13. Ebeid K, Wille S, Hamdy A, Salah T, El-Etreby A, Kern M. Effect of changes in sintering parameters on monolithic translucent zirconia. Dent Mater. 2014 Dec;30(12):e419-24. doi: 10.1016/j.dental.2014.09.003. Epub 2014 Sep 26.

14. Ebeid K, Wille S, Salah T, Wahsh M, Zohdy M, Kern M. Evaluation of surface treatments of monolithic zirconia in different sintering stages. J Prosthodont Res. 2018 Apr;62(2):210-217. doi: 10.1016/j. jpor.2017.09.001. Epub 2017 0ct 9.

15. Hjerppe J, Vallittu PK, Froberg K, and Lassila LV. Effect of sintering time on biaxial strength of zirconium dioxide. Dent Mater. 2009 Feb;25(2):166-71. doi: 10.1016/j.dental.2008.05.011. Epub 2008 Jul 15.

16. Ozcan M, Melo RM, Souza R0, Machado JP, Felipe Valandro L, Botttino MA. Effect of air-particle abrasion protocols on the biaxial flexural strength, surface characteristics and phase transformation of zirconia after cyclic loading. J Mech Behav Biomed Mater. 2013 Apr;20:19-28. doi: 10.1016/j.jmbbm.2013.01.005. Epub 2013 Jan 29.

17. Yener ES, Ozcan M, Kazazoğlu E. The effect of glazing on the biaxial flexural strength of different zirconia core materials. Acta Odontol Latinoam. 2011;24(2):133-40.

18. Salihoglu Yener E, Ozcan M, and Kazazoglu E. A comparative study of biaxial flexural strength and Vickers microhardness of different zirconia materials: Effect of glazing and thermal cycling. Brazilian Dental Science. 2015;18(2):19-30.

19. K Shah, Holloway JA, and Denry IL, Effect of coloring with various metal oxides on the microstructure, color, and flexural strength of 3Y-TZP. J Biomed Mater Res B Appl Biomater. 2008 Nov;87(2):329-37. doi: 10.1002/jbm.b.31107.

20. Sen N, Sermet IB, and Cinar S. Effect of coloring and sintering on the translucency and biaxial strength of monolithic zirconia. J Prosthet Dent. 2018 Feb;119(2):308.e1-308.e7. doi: 10.1016/j.prosdent.2017.08.013. Epub 2017 Nov 15.

21. Zhang Y. Making yttria-stabilized tetragonal zirconia translucent. Dent Mater. 2014 0ct;30(10):1195-203. doi: 10.1016/j.dental.2014.08.375. Epub 2014 Sep 2

22. Zhang F, Inokoshi M, Batuk M, Hadermann J, Naert I, Van Meerbeek B, et al. Strength, toughness and aging stability of highly-translucent Y-TZP ceramics for dental restorations. Dent Mater. 2016 Dec;32(12):e327-e337. doi: 10.1016/j.dental.2016.09.025. Epub 2016 Sep 30. 
23. Hjerppe J, Narhi T, Froberg K, Vallittu PK, and Lassila LV. Effect of shading the zirconia framework on biaxial strength and surface microhardness. Acta Odontol Scand. 2008;66(5):262-7.

24. E Orhun, The effect of coloring liquid dipping time on the fracture load and color of zirconia ceramics. J Adv Prosthodont. 2017;9(1):67-73.
25. Subasi MG, Alp G, Johnston WM, Yilmaz B, Effects of fabrication and shading technique on the color and translucency of new-generation translucent zirconia after coffee thermocycling. J Prosthet Dent. 2018;120(4):603-8.

26. Camposilvan E, Leone R, Gremillard L, Sorrentino R, Zarone F, Ferrari $\mathrm{M}$, et al. Aging resistance, mechanical properties and translucency of different yttria-stabilized zirconia ceramics for monolithic dental crown applications. Dent Mater. 2018;34(6):879-90.

\section{Kamal Ebeid}

\section{(Corresponding address)}

Department of Fixed Prosthodontics, Faculty of Dentistry, Ain Shams University

Organization of African Unity Street, Cairo, Egypt

Date submitted: 2018 Nov 21

kamal_ebeid@dent.asu.edu.eg 